Article

\title{
Catalytic Fast Pyrolysis of Forestry Wood Waste for Bio-Energy Recovery Using Nano-Catalysts
}

\author{
Cheng $\mathrm{Li} @$, Xiaochen Yue, Jun Yang, Yafeng Yang, Haiping Gu * and Wanxi Peng * \\ School of Forestry, Henan Agricultural University, Zhengzhou 450002, China; lichengzzm@163.com (C.L.); \\ yuexiaochen95@163.com (X.Y.); yangjun940207@163.com (J.Y.); yafengyangzz@163.com (Y.Y.) \\ * Correspondence: guhaiping.1357@163.com (H.G.); pengwanxi@hau.edu.cn (W.P.)
}

Received: 12 September 2019; Accepted: 16 October 2019; Published: 18 October 2019

\begin{abstract}
Fast pyrolysis is envisioned as a promising technology for the utilization of forestry wood waste (e.g., widely available from tree logging) as resources. In this study, the potential of an innovative approach was explored to convert forestry wood waste of Vernicia fordii (VF) into energy products based on fast pyrolysis combined with nano-catalysts. The results from fast pyrolysis using three types of nano-catalysts showed that the distribution and composition of the pyrolytic product were affected greatly by the type of nano-catalyst employed. The use of nano- $\mathrm{Fe}_{2} \mathrm{O}_{3}$ and nano-NiO resulted in yields of light hydrocarbons (alkanes and olefins) as $38.7 \%$ and $33.2 \%$, respectively. Compared to the VF sample, the use of VF-NiO and $\mathrm{VF}-\mathrm{Fe}_{2} \mathrm{O}_{3}$ led to significant increases in the formation of alkanes (e.g., from $14 \%$ to $26 \%$ and $31 \%$, respectively). In addition, the use of nano-NiO and nano- $\mathrm{Fe}_{2} \mathrm{O}_{3}$ catalysts was found to promote the formation of acid, aromatics, and phenols that can be used as chemical feedstocks. The $\mathrm{NiO}$ catalyst affected the bio-oil composition by promoting lignin decomposition for the formation of aromatics and phenolics, which were increased from $9.52 \%$ to $14.40 \%$ and from $1.65 \%$ to $4.02 \%$, respectively. Accordingly, the combined use of nano-catalysts and fast pyrolysis can be a promising technique for bio-energy applications to allow efficient recovery of fuel products from forestry wood waste.
\end{abstract}

Keywords: pyrolysis; catalyst; wood; waste; energy

\section{Introduction}

Due to the extensive exploitation and consumption of non-renewable fossil fuels, environmental pollution, climate change, and ecological damage have become increasingly severe [1-3]. Therefore, the development and extension of alternative energy resources are required [4-6]. Biomass is extremely abundant in nature in various types as representative renewable resource [7]. It is generally present in diverse forms such as agricultural crops, crop residues, woods, forest industry wastes, and aquatic plants [8-10]. For a long time, biomass was directly burned as a fuel to obtain energy, which inflicted severe environmental pollution. Therefore, the valorization of biomass into biofuels or fine chemicals via chemical conversion technologies could lessen the dependence of modernization on fossil resources [11], thereby alleviating the bottleneck associated with the shrinking fossil resource reserves [12,13]. Furthermore, the efficient utilization of carbon-neutral biomass is vital to mitigate the greenhouse effect provoked by the combustion and/or inappropriate handling of biomass. Hence, an alternative technology is required to facilitate effective conversion of biomass into fuels or fine chemicals of good quality [6,14-16].

Forestry waste can be referred to as the residues produced in the process of forestry production and processing such as the residues of tree cutting and wood processing, urban landscaping waste, forest tending and thinning residues, economic forest pruning waste, and waste wood materials. According to the calculation of all the above waste, there were about 454.04 million tons of forestry 
waste in China in 2014 [17]. The pruning waste from commercial forests was about 141.74 million tons [17]. Vernicia fordii is widely planted in China as an important economic tree species with high utilization and economic value. A good amount of pruning waste is generated from Vernicia fordii trees each year, which is often discarded or burned. Therefore, how to make full use of such waste has great significance for the high value utilization of biomass waste.

The use of catalysts in fast pyrolysis can potentially improve the quality of bio-oil. These catalysts could lead to an upgrade of the properties of bio-oil and enhance the formation of valuable chemicals [18]. Banks et al. [19] investigated the bio-oils produced from fast pyrolysis of alkali metal (potassium) impregnated biomass. The potassium promoted the pyrolytic decomposition biomass (cellulose and hemicellulose) and the formation of levoglucosan and hydroxymethyl cyclopentene derivatives. Chen et al. [20] studied fast pyrolysis of biomass with metal nitrides (TiN or GaN) for furfural production, whereby direct decomposition of oligosaccharides was catalyzed to yield furfural. Through catalysis, aromatics could also be obtained from lignin depolymerization during biomass pyrolysis [21-24]. $\mathrm{NiO}$ and $\mathrm{Fe}_{2} \mathrm{O}_{3}$ have attracted extensive interest in recent years for their catalytic and magnetic properties [25-27]. Nanometer-sized $\mathrm{NiO}$ and $\mathrm{Fe}_{2} \mathrm{O}_{3}$ have many improved properties compared to their pristine (or bulk) forms. It was found that nano-NiO particles exerted more effective catalytic effects than micro-NiO particles in biomass pyrolysis [24]. Khelfa et al. [28], using $\mathrm{Fe}_{2} \mathrm{O}_{3}$ as catalyst, studied the catalytic pyrolysis and gasification of Miscanthus giganteus. Their results showed that $\mathrm{Fe}_{2} \mathrm{O}_{3}$ as a catalyst was active in gasification and hydrogen production. In addition, $\mathrm{Fe}_{2} \mathrm{O}_{3}$ could break down the tar produced and improved the partial oxidation of phenols during the thermal degradation of the biomass. Despite the potential utility of these catalysts, no reports have been made to describe the effects of the nano- $\mathrm{NiO}$ and nano- $\mathrm{Fe}_{2} \mathrm{O}_{3}$ catalysts on the fast pyrolysis of forestry wood waste.

In light of the high economical value and high availability of forestry wood waste (Vernicia fordii), an integrated approach is proposed to combine fast pyrolysis with nano-catalysts $\left(\mathrm{NiO}\right.$ and $\left.\mathrm{Fe}_{2} \mathrm{O}_{3}\right)$ to convert forestry wood waste (Vernicia fordii) into energy products. Characterization of the wood waste was first performed followed by pyrolysis using three types of nano-catalysts to investigate their influence on the distribution and composition of the pyrolytic product. Thermogravimetric analysis and pyrolysis gas chromatography-mass spectrometry were used to analyze the chemical components of the bio-oil produced and to compare the catalytic effect of nano-catalysts on fast pyrolysis of Vernicia fordii wood waste.

\section{Materials and Methods}

\subsection{Materials}

Forestry wood waste of Vernicia fordii wood (VF) was collected from Funiu Mountain, China. The VF was ground and screened to a particle size range of $149-177 \mu \mathrm{m}$ before its preservation at $-3^{\circ} \mathrm{C}$ under vacuum conditions. Methanol, benzene, and ethanol of chromatographic grade were purchased from Hunan Huihong Reagent Co., Ltd., China. The nano-catalysts $\left(\alpha-\mathrm{Fe}_{2} \mathrm{O}_{3}(30 \mathrm{~nm}\right.$, spherical, $99.5 \%)$ and $\mathrm{NiO}(60-120 \mathrm{~nm}$, spherical, 99.5\%)) used in this work were directly procured from Shanghai Macklin Biochemical Co., Ltd. For the current study, the mass of VF was fixed as $20 \mathrm{~g}$ with and without the addition of $1 \mathrm{wt} \%$ nano-catalysts either individually or as a mixture $\left(\mathrm{NiO}, \mathrm{Fe}_{2} \mathrm{O}_{3}\right.$, or $\mathrm{NiO} / \mathrm{Fe}_{2} \mathrm{O}_{3}$ mixture (equal mass of $\mathrm{NiO}$ and $\left.\mathrm{Fe}_{2} \mathrm{O}_{3}\right)$ ). Thus, there were four pyrolysis samples investigated, which were designated as $\mathrm{VF}, \mathrm{VF}-\mathrm{NiO}, \mathrm{VF}-\mathrm{Fe}_{2} \mathrm{O}_{3}$, and $\mathrm{VF}-\mathrm{NiO} / \mathrm{Fe}_{2} \mathrm{O}_{3}$. The flow chart of forestry wood waste procedure is shown in Figure 1. 


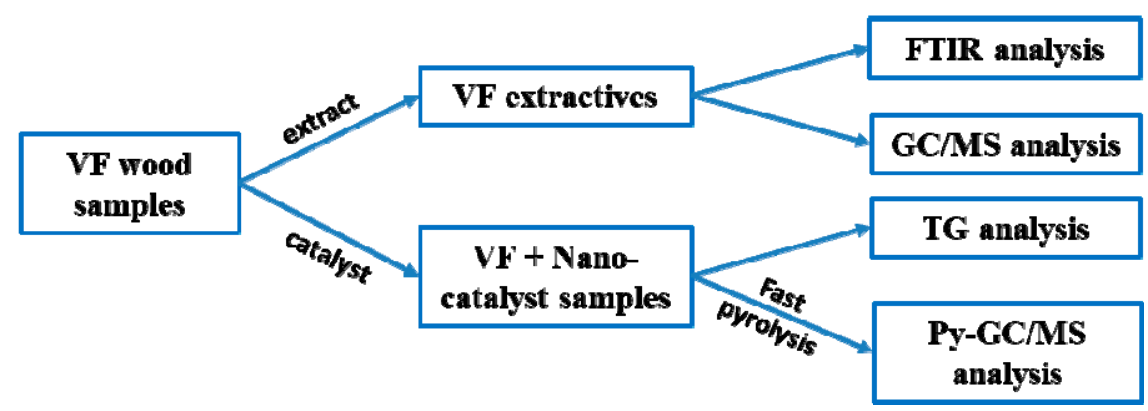

Figure 1. The flow chart of forestry wood waste pyrolysis procedure (Note: VF is the abbreviation of Vernicia fordii).

\subsection{Characterization of Forestry Wood Waste (Vernicia fordii Wood)}

Three pairs of cotton bags and cotton thread were soaked in methanol, ethanol/benzene (1:1), and ethanol/ether (1:1) solution for $12 \mathrm{~h}$, respectively, to remove possible contaminants that possibly arose as interference. About $40 \mathrm{~g}$ of Vernicia fordii wood (VF) with a particle size range of 149-177 $\mu \mathrm{m}$ was parceled into three cotton bags, which were later tied and sewed with the cotton thread. Henceforth, the extraction of VF was conducted in the Soxhlet extractor for $6 \mathrm{~h}$ at $60^{\circ} \mathrm{C}$ with $300 \mathrm{~mL}$ solvents such as methanol, ethanol/benzene, and ethanol/ether. After extraction, the solvents were removed via rotary evaporation $\left(55^{\circ} \mathrm{C}, 10-50 \mathrm{~Pa}\right)$ and desiccated with anhydrous sodium sulfate. Prior to any characterization, the resulting VF extracts were stored at $-3^{\circ} \mathrm{C}$. Then, the VF extracts were subjected to FTIR and GC/MS for their functional groups and chemical compositions, individually. By using an FTIR spectrophotometer (IR100), the KBr discs containing $1 \mathrm{wt} \%$ finely ground sample were scanned with infrared radiation from 4000 to $500 \mathrm{~cm}^{-1}$. The GC/MS analysis was executed with a GC/MS (Agilent 7890B-5977A) equipped with an HP-5MS column $(30 \mathrm{~m} \times 25 \mu \mathrm{m} \times 0.25 \mu \mathrm{m})$. The GC was initiated at $50{ }^{\circ} \mathrm{C}$, heated to $250{ }^{\circ} \mathrm{C}$ with a ramping rate of $8{ }^{\circ} \mathrm{C} / \mathrm{min}$, and finally heated to $300{ }^{\circ} \mathrm{C}$ with a ramping rate of $5{ }^{\circ} \mathrm{C} / \mathrm{min}$. Meanwhile, the inlet temperature, column flow, split ratio, and carrier gas were $250^{\circ} \mathrm{C}, 1.0 \mathrm{~mL} / \mathrm{min}, 20: 1$, and helium, respectively. For the MS, the electrons of samples were ionized with electron energy of $70 \mathrm{eV}$ from the ion source at $230{ }^{\circ} \mathrm{C}$, while the temperature of the quadrupole was $150{ }^{\circ} \mathrm{C}$. The MS program was capable of detecting compounds in the mass range of 30-600 amu. For qualitative spectrum matching, the Wiley 7n.1 standard spectrum was used [29].

\subsection{Catalytic Fast Pyrolysis of Forestry Wood Waste (Vernicia fordii Wood) Using Nano-Catalyst}

The fast pyrolysis of forestry wood waste (Vernicia fordii wood, VF) using nano-catalysts was investigated by TG and Py-GC/MS analysis. One pristine VF and three amended VF samples (VF-NiO, $\mathrm{VF}-\mathrm{Fe}_{2} \mathrm{O}_{3}$, and $\mathrm{VF}-\mathrm{NiO} / \mathrm{Fe}_{2} \mathrm{O}_{3}$ ) were analyzed to scrutinize the effect of nano-catalyst addition. In this study, the catalyst-to-feed-ratio was 1 to 100 . For TG analysis, about $5 \mathrm{mg}$ of samples were loaded on the platinum pan inside a thermal gravimetric analyzer (TA Instruments Q50) to examine the thermal decomposition of samples. The non-isothermal TG curves were obtained by heating the samples from ambient temperature to $850^{\circ} \mathrm{C}$ under $\mathrm{N}_{2}$ atmosphere with two different heating rates $\left(20^{\circ} \mathrm{C} / \mathrm{min}\right.$ and $\left.55^{\circ} \mathrm{C} / \mathrm{min}\right)[30]$.

In order to conduct in-situ analysis of the bio-oil contents, the samples were further analyzed via Py-GC/MS analysis by using integrated pyrolysis-GC/MS instrumentation (CDS Pyroprobe 5000-Agilent 7890B-5977A). In the pyrolyzer, the samples were subjected to fast pyrolysis via heating under inert helium flow to $850^{\circ} \mathrm{C}$ at a high heating rate of $250^{\circ} \mathrm{C} / \mathrm{s}$, whereby the maximum pyrolysis temperature was maintained for $15 \mathrm{~s}$. Apart from creating an inert environment, the helium also acted as a carrier gas that delivered the vaporized bio-oil from the pyrolyzer to the GC/MS. The temperature of the pyrolysis product transfer line and injection valve was set to $300{ }^{\circ} \mathrm{C}$ to prevent the recondensation of vaporized bio-oil within the instrumentation. The GC was furnished with a capillary column (TR-5MS) and operated in split mode, wherein the split ratio and total flow rate used were 50:1 and 
$50 \mathrm{~mL} / \mathrm{min}$, respectively. The GC oven initial temperature was $40^{\circ} \mathrm{C}$ (holding $2 \mathrm{~min}$ ), heated to $120^{\circ} \mathrm{C}$ (ramping rate of $5{ }^{\circ} \mathrm{C} / \mathrm{min}$ ), and then increased to $200^{\circ} \mathrm{C}$ (holding $15 \mathrm{~min}$ at ramping rate of $10^{\circ} \mathrm{C} / \mathrm{min}$ ). For MS, the temperature of electron ionization and scanning range were fixed as $230^{\circ} \mathrm{C}$ and 28-500 amu, respectively.

It is known that the GC/MS technique cannot quantify the chemical compounds. However, there is a considered linear relationship between the chromatographic peak area of a compound and its quantity. Therefore, in this study, the peak area and peak area \% values with different catalysts were calculated and used to reveal the different yields for each product [31,32].

\section{Results and Discussion}

\subsection{Characterization of Forestry Wood Waste (Vernicia fordii Wood) Extracts}

Through GC/MS analysis, the total ion chromatograph of VF extracts from Soxhlet extraction with different solvents (methanol, ethanol/benzene, or ethanol/ether) were acquired. Supplementary Materials Figures S2-S4 depict the total ion chromatographs while the chemical composition of VF extracts are tabulated in Tables S2-S4. The compositional difference of VF extracts was rendered by the different affinity of solvents towards the extractable components of different polarities in VF. From Figures S2-S4 and Tables S2-S4 in Supplementary Materials, a total of 77 distinct chemical compounds were identified from the GC/MS analysis of VF extracts. For ease of discussion, these compounds were classified in terms of common functional groups (e.g., acids, alcohols, aldehydes, esters, amines, phenols, ketones, aromatics, olefins, and saccharides). In Supplementary Materials, Figure S5 presents the chemical composition of Vernicia fordii wood (VF) extracts that had been sorted into the aforementioned functional groups.

The GC/MS analysis confirmed that the VF extracts contained high value chemical constituents, which have widely promising and potential applications. For instance, linoleic acid has several medical applications such as lowering blood lipids, softening blood vessels, lowering blood pressure, and reducing cardiovascular diseases. In a few reports, a high potential of linoleic acid was suggested for the prevention of cancer, inflammation, and arthritis [33]. In addition, the $n$-hexadecanoic acid in VF could serve as a renewable feedstock for the production of soaps, cosmetics, and industrial mold release agents. Sitosterol can lower serum cholesterol while butorphanol can act as a pain reliever [34,35]. The esters of VF can be used as the precursors for emulsifiers, wetting agents, stabilizers, and plasticizers. The aromatics of VF could be utilized for the synthesis of more complex compounds through substitution reactions of simple aromatics. In brief, VF possesses a wide range of useful chemical compounds, which could be used as feedstocks in medical and industrial applications.

\subsection{Catalytic Fast Pyrolysis of Forestry Wood Waste (Vernicia fordii Wood)}

Lignocellulosic biomass can be divided into three major components: cellulose, hemicellulose, and lignin $[36,37]$. Cellulose is a polymer formed by the polymerization of glucose through $\beta$-1,4-glycosidic bonds. Hemicellulose is a polymer formed by the polymerization of hexose and pentose sugars. Lignin is mainly composed of guaiacol, syringyl, and para-hydroxy-phenyl alcohol, which are relatively complex and difficult to depolymerize [38]. As a biomass, the VF is also mainly composed of three lignocellulosic components called cellulose, hemicellulose, and lignin. The thermal decomposition of VF is very complex owing to the different reactivity and stability of these lignocellulosic components as well as the interactions between them. Based on the thermogravimetric (TG) analysis, the thermal decomposition of Vernicia fordii wood samples (e.g., VF, VF-NiO, VF- $\mathrm{Fe}_{2} \mathrm{O}_{3}$, and $\mathrm{VF}-\mathrm{NiO} / \mathrm{Fe}_{2} \mathrm{O}_{3}$ ) was elucidated with fast pyrolysis at two specified heating rates $\left(25^{\circ} \mathrm{C} / \mathrm{min}\right.$ and $\left.55{ }^{\circ} \mathrm{C} / \mathrm{min}\right)$. Figure 2 presents TG and the first derivative of thermogravimetric (DTG) curves of VF samples.

All the VF samples went through three stages during pyrolysis (Figure 2). During the first stage, when the temperature increased from room temperature to $35^{\circ} \mathrm{C}$ to $200{ }^{\circ} \mathrm{C}$, the weight loss of all samples mainly involved the evaporation of water and small molecular weight components. 
The second decomposition stage occurred in the temperature range of $200-400{ }^{\circ} \mathrm{C}$, when all DTG curves (Figure 2) showed that there was a primary peak of weight loss, which could be due to the process of decomposition of cellulose, hemicellulose, and part of lignin [39-41]. According to a report by Yu et al. [24], with increasing temperature, the decomposition of cellulose increased rapidly and was almost completed at $400^{\circ} \mathrm{C}$. According to Biagini's report, the onset temperature of hemicellulose (xylan as model compound) was $253^{\circ} \mathrm{C}$. The cellulose exhibited the maximum weight loss in the range of $200-400{ }^{\circ} \mathrm{C}$. The onset and maximum weight loss were 319 and $354{ }^{\circ} \mathrm{C}$ [42]. At around $200{ }^{\circ} \mathrm{C}$, the decomposition of lignin can be attributed to the dehydration reactions. Then, the cleavage of $\alpha-$ and $\beta$-aryl-alkyl-ether linkages occurred at around $300{ }^{\circ} \mathrm{C}$. Meanwhile, the aliphatic side chains started to split off from the aromatic ring of lignin $[43,44]$. These results are consistent with our observation made in this work.

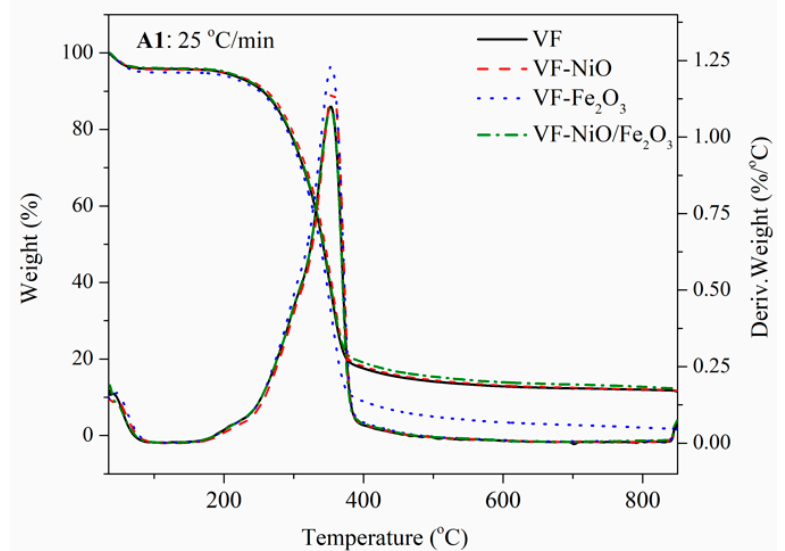

(a)

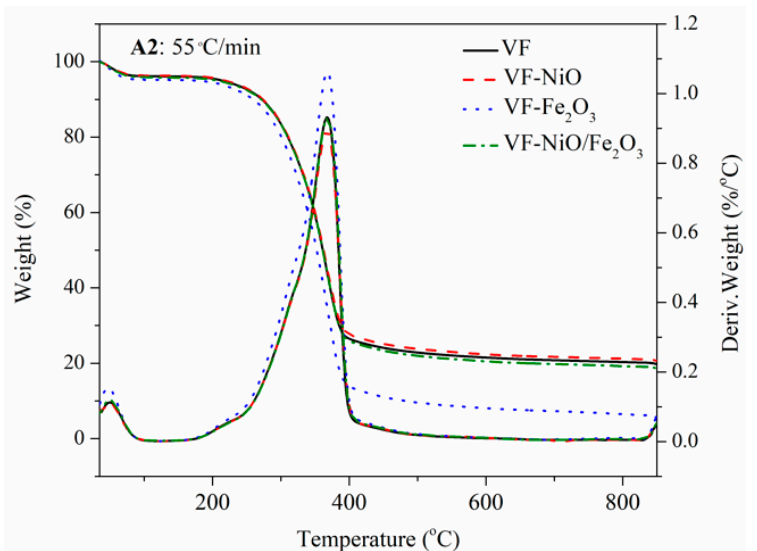

(b)

Figure 2. TG and DTG curves of Vernicia fordii wood samples at two different heating rates: $25^{\circ} \mathrm{C} / \mathrm{min}$ (a) and $55^{\circ} \mathrm{C} / \mathrm{min}(\mathbf{b})$.

Compared to cellulose and lignin, hemicellulose is the most unstable component in Vernicia fordii wood. The onset of its decomposition at about $200^{\circ} \mathrm{C}$ is assumed to reflect a lower degree of polymerization compared to cellulose and lignin [45]. The primary weight loss occurred in the temperature range of $320-400{ }^{\circ} \mathrm{C}$. In addition, due to the complex stable aromatic rings with various branch structures, the pyrolysis of lignin has been proven to occur continuously through a range of 200-900 ${ }^{\circ} \mathrm{C}$ [46]. At the third stage, above $400{ }^{\circ} \mathrm{C}$, the weight loss was slower and relatively small due to the pyrolysis of lignin and the residues of char [41,47-49].

The thermal decomposition of wood biomass could be influenced by various factors such as temperature, chemical composition, heating rate, etc. [50]. In order to investigate the effect of heating rate on the thermal decomposition of VF and nano-VF samples, the heating rate of $25^{\circ} \mathrm{C}$ and $55^{\circ} \mathrm{C}$ were recorded, as shown in Figures 2 and 3. It can be seen that the heating rate had significant influence on the thermal decomposition of VF and nano-VF samples. With the increase of heating rate, the peak temperatures of all samples were increased from around $354^{\circ} \mathrm{C}$ to around $368^{\circ} \mathrm{C}$. In addition, the weight loss of all the different decomposition stages also obviously was changed as the heating rate increased. Comparing the influence of nano-catalysts, it can be seen that both the TG and DTG curves only experienced slight changes when nano- $\mathrm{NiO}$ catalyst and nano- $\mathrm{NiO} / \mathrm{Fe}_{2} \mathrm{O}_{3}$ were added. During the second stage $\left(200-400^{\circ} \mathrm{C}\right)$, only one peak was observed in the DTG curves of Vernicia fordii (VF). The peak temperature was almost the same with the addition of nano- $\mathrm{Fe}_{2} \mathrm{O}_{3}$, while the weight loss rate increased from $0.9 \% /{ }^{\circ} \mathrm{C}$ to $1.25 \% /{ }^{\circ} \mathrm{C}$. This indicated that the nano- $\mathrm{Fe}_{2} \mathrm{O}_{3}$ catalyst can promote the pyrolysis of cellulose and hemicellulose during this range of temperature, causing the production of more acids and ketone compounds. In the third stage, the varying DTG values indicated that the introduction of the nano- $\mathrm{Fe}_{2} \mathrm{O}_{3}$ catalyst has a significant effect on the decomposition of VF. As seen in 
Figure $3 c$, in the range of $200-400{ }^{\circ} \mathrm{C}$, the weight loss of VF, VF-NiO, VF- $\mathrm{Fe}_{2} \mathrm{O}_{3}$, and $\mathrm{VF}-\mathrm{NiO} / \mathrm{Fe}_{2} \mathrm{O}_{3}$

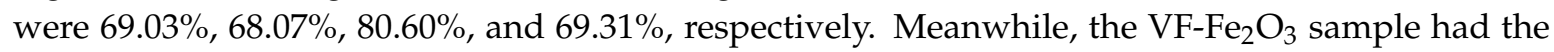
highest weight loss rate $\left(1.06 \% / \mathrm{min}\right.$, Figure 3 , SZ-D2). These indicated that the catalyst of nano- $\mathrm{Fe}_{2} \mathrm{O}_{3}$ improved the decomposition of cellulose and lignin in VF. At $400-800{ }^{\circ} \mathrm{C}$, the weight loss of VF, VF-NiO, VF- $\mathrm{Fe}_{2} \mathrm{O}_{3}$, and VF-NiO/ $\mathrm{Fe}_{2} \mathrm{O}_{3}$ were $6.18 \%, 6.41 \%, 7.39 \%$, and $6.70 \%$, respectively. The $\mathrm{VF}-\mathrm{Fe}_{2} \mathrm{O}_{3}$ sample had the biggest weight loss compared to the others. This indicated that nano- $\mathrm{Fe}_{2} \mathrm{O}_{3}$ promoted the pyrolysis of lignin and the remaining solid residues of cellulose and hemicellulose in the last stage. In addition, we can also see in Figure 3 that the VF- $\mathrm{Fe}_{2} \mathrm{O}_{3}$ sample had the lowest residues, which showed that the VF- $\mathrm{Fe}_{2} \mathrm{O}_{3}$ sample had the biggest weight loss compared to the others. Compared with nano- $\mathrm{NiO}$ and nano- $\mathrm{NiO} / \mathrm{Fe}_{2} \mathrm{O}_{3}$, the catalyst of nano- $\mathrm{Fe}_{2} \mathrm{O}_{3}$ had a significant effect on the whole pyrolysis process of Vernicia fordii wood. The main reason might be attributed to the fact that the nano- $\mathrm{Fe}_{2} \mathrm{O}_{3}$ can promote the breaking of ether bond in the lignin and lignin derivative structures. Nano- $\mathrm{Fe}_{2} \mathrm{O}_{3}$ improved the cleavage of $\alpha$-and $\beta$-aryl-alkyl-ether linkages and the splitting of the aliphatic side chains from the aromatic ring. However, for the catalyst of nano- $\mathrm{NiO} / \mathrm{Fe}_{2} \mathrm{O}_{3}$, the catalysis of nano- $\mathrm{Fe}_{2} \mathrm{O}_{3}$ was restricted by nano-NiO.

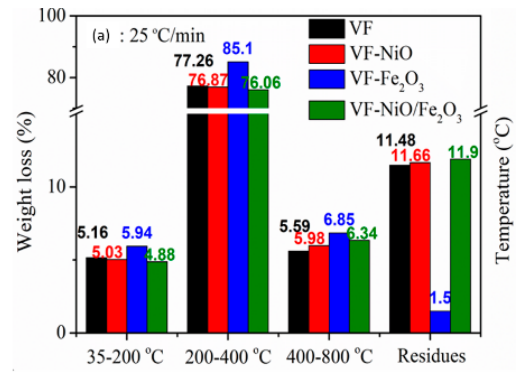

(a)

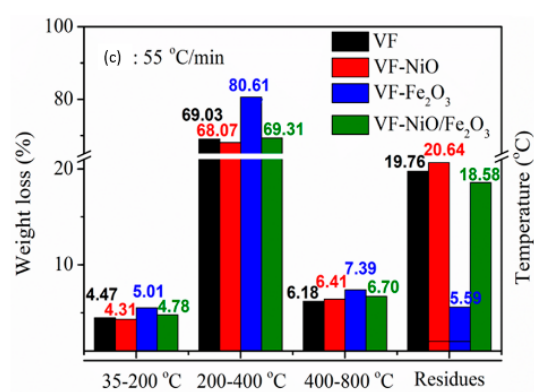

(c)

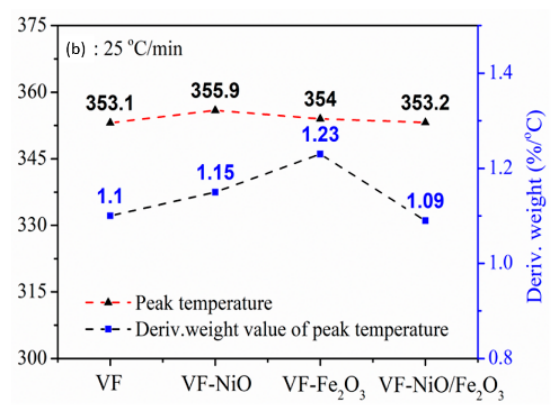

(b)

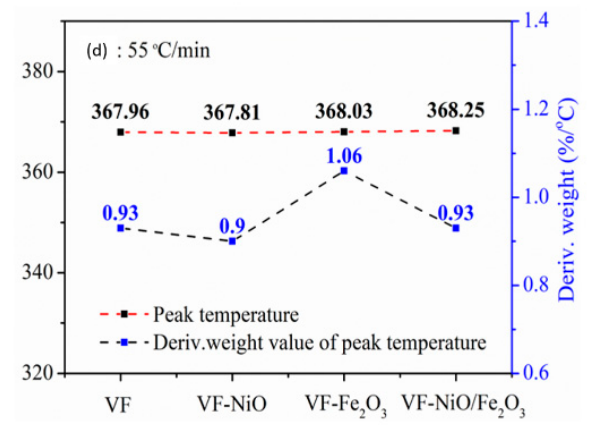

(d)

Figure 3. Thermal properties of Vernicia fordii wood: (a) the weight loss of different decomposition stages at the heating rate of $25^{\circ} \mathrm{C} / \mathrm{min}$; (b) the peak temperature of DTG curves and the decomposition rate $\left(25^{\circ} \mathrm{C} / \mathrm{min}\right)$; (c) the weight loss of different decomposition stages at the heating rate of $55^{\circ} \mathrm{C} / \mathrm{min}$; (d) the peak temperature of DTG curves and the decomposition rate $\left(25^{\circ} \mathrm{C} / \mathrm{min}\right)$.

For the utilization of lignocellulosic biomass, fast pyrolysis is the most felicitous technology since it is two to three times more economical than liquefaction and gasification processes. By fast pyrolysis, lignocellulosic biomass could be ameliorated into a liquid product, which is often known as the bio-oil. However, the bio-oil has an extremely complicated composition, with different proportions of ethers, esters, aldehydes, ketones, phenols, organic acids, aromatics, and alcohol compounds. It is believed that these compounds in the bio-oil could serve as precursors of value-added biofuels and fine chemicals [51,52]. Many studies have been concerned with the mechanisms of biomass pyrolysis, especially in relation to single lignocellulosic components such as lignin, cellulose, and hemicellulose [53-59]. Py-GC/MS is a rapid, reliable, and powerful method to scrutinize biomass 
fast pyrolysis because it facilitates the elucidation of chemical mechanisms by detecting the pyrolysis products [60]. In this study, the bio-oil vapor released from non-catalytic and catalytic pyrolysis VF samples were analyzed in-situ by Py-GC/MS. For all of the VF samples, the total ion chromatograms of their bio-oil vapor are shown in Figure 4, with the product of bio-oil vapor summarized in Supplementary Materials Tables S5-S8. Similar to the VF extracts, a wide range of organic compounds were found in the fast pyrolysis product of VF samples. Likewise, these organic compounds were categorized into common functional groups, viz. acids, alcohols, aldehydes, aromatics, amines, alkanes, esters, furans, ketones, olefins, phenolics, and others. Figure 5 compiles the chemical composition of bio-oil vapor released from the fast pyrolysis of Vernicia fordii wood (VF) samples sorted by common functional groups.
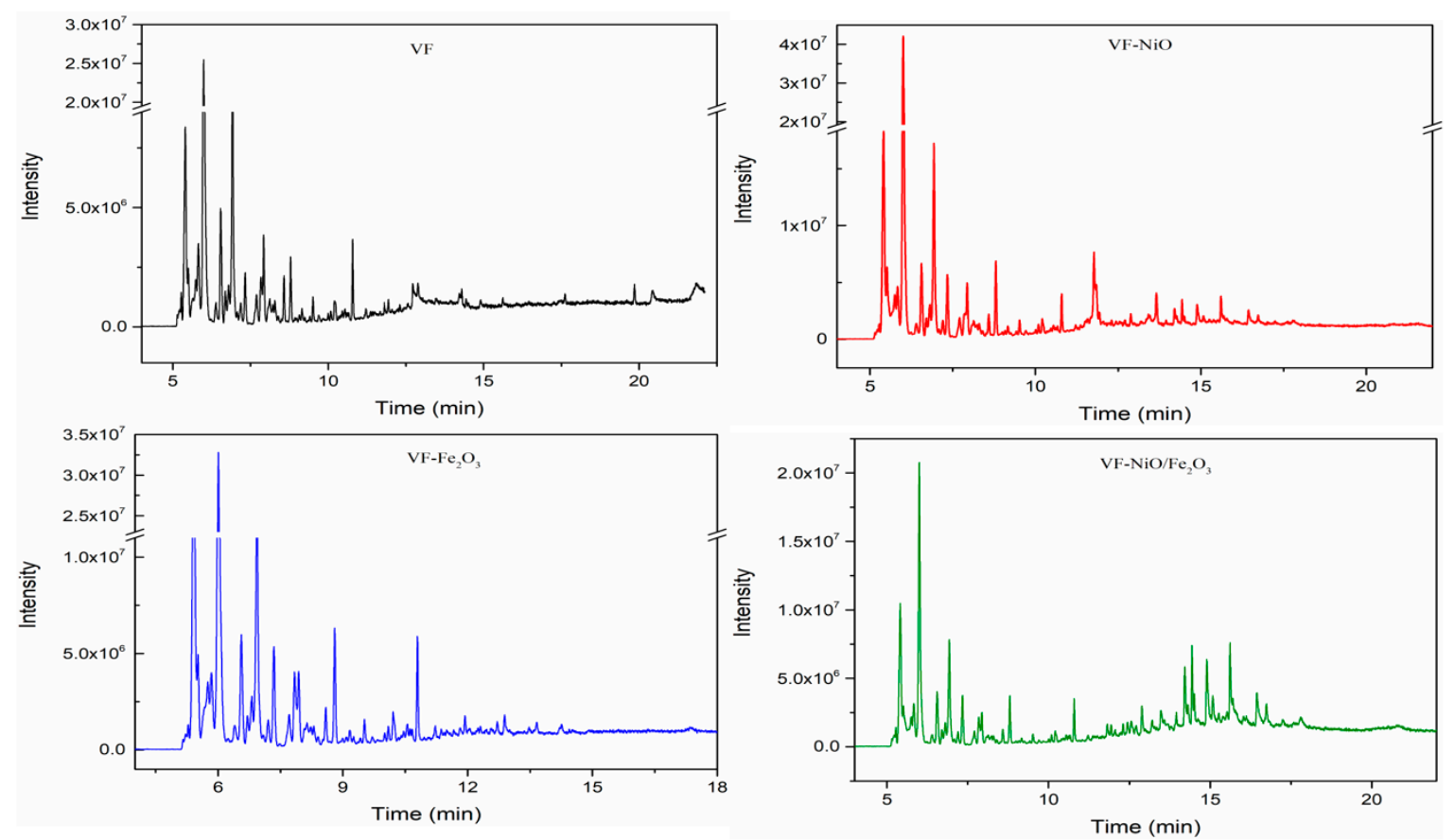

Figure 4. Total ion chromatograms of bio-oil vapor released from the fast pyrolysis of Vernicia fordii wood samples (VF, VF-NiO, VF- $\mathrm{Fe}_{2} \mathrm{O}_{3}$, and $\mathrm{VF}-\mathrm{NiO} / \mathrm{Fe}_{2} \mathrm{O}_{3}$ ).

The Py-GC/MS analysis revealed that the bio-oils from VF, VF-NiO, VF- $-\mathrm{Fe}_{2} \mathrm{O}_{3}$, and VF-NiO/Fe ${ }_{2} \mathrm{O}_{3}$ were composed of 72, 68, 69, and 70 chemical compounds. As observed in Figure 5, non-catalytic pyrolysis of $\mathrm{VF}$ and catalytic fast pyrolysis of $\mathrm{VF}-\mathrm{NiO}, \mathrm{VF}-\mathrm{Fe}_{2} \mathrm{O}_{3}$, and $\mathrm{VF}-\mathrm{NiO} / \mathrm{Fe}_{2} \mathrm{O}_{3}$ almost produced bio-oil with similar product distribution, although the functional group contents were non-identical. The bio-oil from VF was comprised of acids $(0.23 \%)$, alcohols $(29.72 \%)$, aldehydes $(3.24 \%)$, alkanes $(14.43 \%)$, amines $(7.38 \%)$, aromatics $(9.52 \%)$, esters $(1.81 \%)$, furans $(9.01 \%)$, ketones $(4.03 \%)$, phenolics $(1.65 \%)$, olefines $(14.53 \%)$, and others $(4.45 \%)$. The bio-oil from VF was rich with 2-methyl-3-buten-1-ol $(28.00 \%)$, ethylcyclopropane (11.88\%), 1,3-butadiene (10.60\%), 3-methylfuran (4.95\%), 3-iodo- $1 \mathrm{H}$-pyrazole $(3.67 \%)$, 2-butenal $(2.99 \%)$, felbamate $(2.14 \%)$, toluene $(2.10 \%)$, and benzene $(1.83 \%)$.

Meanwhile, the bio-oil from VF-NiO was made up of acids (1.17\%), alcohols (27.83\%), aldehydes $(0.66 \%)$, alkanes $(25.91 \%)$, amines $(1.92 \%)$, aromatics $(14.40 \%)$, esters $(2.33 \%)$, furans $(6.96 \%)$, ketones $(4.07 \%)$, phenolics $(4.02 \%)$, olefines $(7.32 \%)$, and others $(3.43 \%)$. The bio-oil from VF-NiO primarily contained 2-methyl-3-buten-1-ol (25.07\%), methylenecyclopropane (12.12\%), ethylcyclopropane (9.67\%), dimethylethylborane (4.12\%), 4,4'-methylenedianiline (4.02\%), 2-methylfuran(3.44\%), 1,3-pentadiene $(3.30 \%)$, toluene $(2.65 \%)$, 3-iodo- $1 \mathrm{H}$-pyrazole $(2.64 \%)$, benzene $(2.63 \%), 1,3$-butadien-1-ol $(2.15 \%)$, 3-hexen-1-yne (1.54\%), $L-\beta$-homoserine (1.17\%), and furfural (1.15\%). 
For VF- $\mathrm{Fe}_{2} \mathrm{O}_{3}$, its bio-oil was comprised of acids (3.23\%), alcohols (29.01\%), aldehydes $(0.40 \%)$, alkanes $(30.78 \%)$, amines $(2.19 \%)$, aromatics $(9.56 \%)$, esters $(0.28 \%)$, furans $(9.78 \%)$, ketones $(2.86 \%)$, phenolics $(0.84 \%)$, olefines $(7.91 \%)$, and others $(3.14 \%)$. The bio-oil of $\mathrm{VF}-\mathrm{Fe}_{2} \mathrm{O}_{3}$ was abundant with 2-methyl-3-buten-1-ol (25.77\%), methylenecyclopropane (17.05\%), ethylcyclopropane (10.58\%), 2-methylfuran (4.06\%), 1,3-pentadiene (3.90\%), benzene (3.28\%), toluene (3.21\%), 3-iodo- $1 \mathrm{H}$-pyrazole $(2.87 \%)$, acetic acid (2.86\%), dimethylethylborane (2.51\%), furfural (2.42\%), 1,3-butadien-1-ol (2.29\%), 2,5-dimethylfuran (1.34\%), 1-penten-3-one (1.13\%), lidocaine (1.10\%), and $p$-xylene $(0.95 \%)$, respectively.

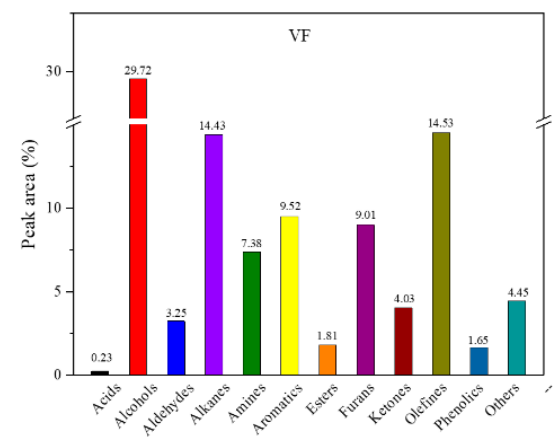

(a)

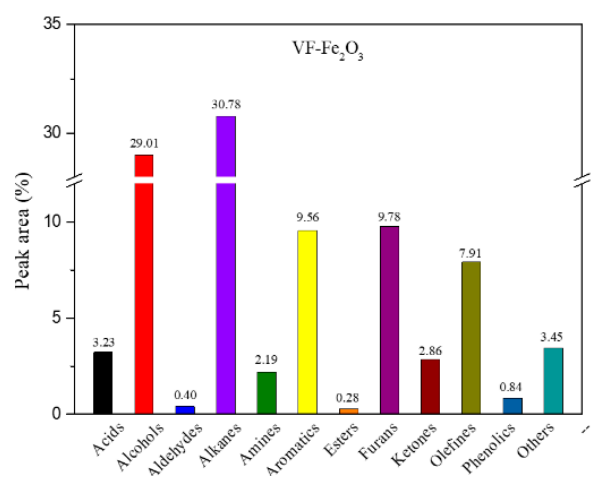

(c)

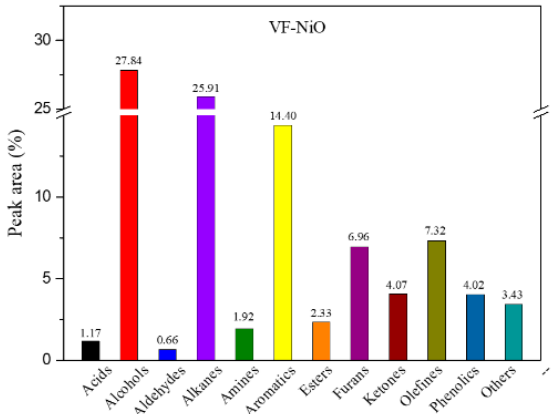

(b)

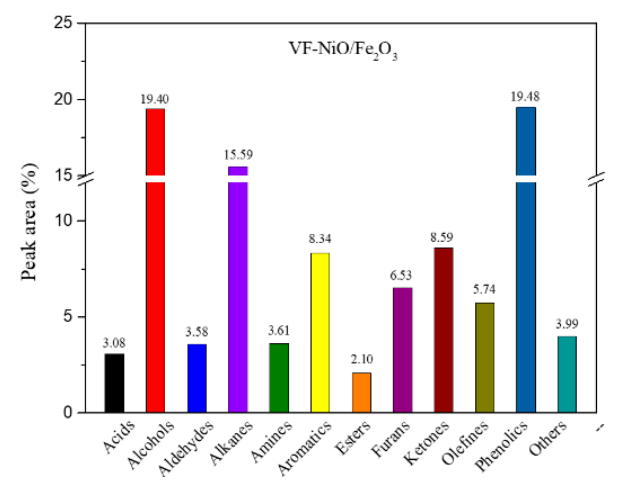

(d)

Figure 5. Chemical composition of bio-oil vapor released from fast pyrolysis of Vernicia fordii wood (VF) samples that were sorted by common functional groups. (a) $\mathrm{VF}$, (b) $\mathrm{VF}-\mathrm{NiO}$, (c) $\mathrm{VF}-\mathrm{Fe}_{2} \mathrm{O}_{3}$, and (d) $\mathrm{VF}-\mathrm{NiO} / \mathrm{Fe}_{2} \mathrm{O}_{3}$.

The constituents of $\mathrm{VF}-\mathrm{NiO} / \mathrm{Fe}_{2} \mathrm{O}_{3}$ bio-oil were acids (3.08\%), alcohols $(19.40 \%)$, aldehydes $(3.58 \%)$, alkanes $(15.59 \%)$, amines $(3.61 \%)$, aromatics $(8.34 \%)$, esters $(2.10 \%)$, furans $(6.53 \%)$, ketones $(8.59 \%)$, phenolics $(19.48 \%)$, olefines $(5.74 \%)$, and others $(3.99 \%)$. The bio-oil of $\mathrm{VF}-\mathrm{NiO} / \mathrm{Fe}_{2} \mathrm{O}_{3}$ was rich in 2-methyl-3-buten-1-ol (17.25\%), methylenecyclopropane (9.48\%), ethylcyclopropane (6.08\%), isoeugenol $(4.14 \%)$, acetoveratrone (3.58\%), 4-vinylguaiacol (3.41\%), DL-2-aminoadipic acid $(3.06 \%)$, syringol (2.92\%), 2-methylfuran (2.87\%), 4-allyl-2,6-dimethoxyphenol (2.67\%), 3-iodo-1H-pyrazole $(2.56 \%)$, benzene $(2.34 \%), 1,3$-pentadiene $(2.33 \%)$, toluene $(1.94 \%)$, vanillin $(1.64 \%)$, furfural $(1.44 \%)$, piperonal $(1.40 \%)$, guaiacol $(1.40 \%)$, creosol $(1.38 \%)$, 3-hexen-1-yne $(1.16 \%)$, and anandamide $(1.08 \%)$.

When the $\mathrm{NiO}$ catalyst was introduced, the aldehyde, amine, furan, and olefin products in the VF bio-oil decreased significantly, but aromatic, alkane, and phenolic compounds increased remarkably (Figure 5). In the presence of $\mathrm{NiO}$, the peak area proportion of aromatics and phenolics increased from 9.52 to $14.40 \%$ and from 1.65 to $4.02 \%$, respectively. Thus, the NiO catalyst affected the bio-oil composition by promoting lignin decomposition for the formation of aromatics and phenolics. Meanwhile, the VF bio-oil produced in the presence of $\mathrm{Fe}_{2} \mathrm{O}_{3}$ had a greater proportion of alkanes and furans than that of non-catalytic pyrolysis at the expense of lower productions of aldehydes, amines, esters, ketones, and olefins. Seemingly, the bio-oil of $\mathrm{VF}$ and $\mathrm{VF}-\mathrm{Fe}_{2} \mathrm{O}_{3}$ had almost similar 
peak area proportions of aromatics $(9.52 \%$ and $9.56 \%$, respectively); nonetheless, the distribution of the aromatics was different. In the presence of $\mathrm{Fe}_{2} \mathrm{O}_{3}$, the slight increment of furans and drastic decrement of aldehydes implied the inhibition of cellulose pyrolysis by the $\mathrm{Fe}_{2} \mathrm{O}_{3}$ catalyst. Furthermore, the lower proportion of phenols and aromatics in the bio-oil of VF- $\mathrm{Fe}_{2} \mathrm{O}_{3}$ than that of VF eventually corroborated the catalytic effect of $\mathrm{Fe}_{2} \mathrm{O}_{3}$ on lignin pyrolysis. The $\mathrm{Fe}_{2} \mathrm{O}_{3}$ catalyst was also effective to produce VF bio-oil with high hydrocarbon yield.

Moreover, the $\mathrm{NiO} / \mathrm{Fe}_{2} \mathrm{O}_{3}$ mixture had a poor performance in forming olefins, alkanes, and alcohols. Hydrocarbons have high value in the fuel industry [61]. The $\mathrm{NiO} / \mathrm{Fe}_{2} \mathrm{O}_{3}$ completely converted acids, aldehydes, and sugars besides significantly reduced furans. The synergistic effect between $\mathrm{NiO}$ and $\mathrm{Fe}_{2} \mathrm{O}_{3}$ caused substantial enhancement of ketones and phenols, whereby phenols and their alkylated derivatives are useful chemical precursors. Due to the high heating value, olefines and alkanes have a high value for fuel applications. The catalytic pyrolysis of $\mathrm{VF}$ over $\mathrm{NiO}$ and $\mathrm{Fe}_{2} \mathrm{O}_{3}$ considerably increased the formation of alkanes in the VF bio-oil from $14.43 \%$ to $25.91 \%$ and $30.78 \%$ peak areas, respectively (Figure 5). There was a disparity in the bio-oils between $\mathrm{VF}-\mathrm{NiO} / \mathrm{Fe}_{2} \mathrm{O}_{3}$ and other samples since the employment of $\mathrm{NiO} / \mathrm{Fe}_{2} \mathrm{O}_{3}$ gave rise to the highest yield of ketones and phenolics.

\section{Conclusions}

In this study, the solvent extracts were analyzed by FTIR and GC-MS methods, which revealed that the Vernicia fordii wood contained a large number and diversity of chemical compounds. These natural product active molecules of the Vernicia fordii wood could be used as drug and biomedical active ingredients, further indicating that Vernicia fordii wood extractives have broad application prospects as raw materials in industrial and medical fields. The Py-GC-MS analysis indicated that the catalyst type significantly influenced the compositions of the pyrolysis of the Vernicia fordii wood. The results revealed that the nano- $\mathrm{NiO}$ and nano- $\mathrm{Fe}_{2} \mathrm{O}_{3}$ catalysts influenced the formation of acid, aromatics, phenols, and alkanes compounds, and inhibited the formation of olefins and amines. In the presence of nano-NiO, the formation of aromatics and phenolics was increased from $9.52 \%$ to $14.40 \%$ and from $1.65 \%$ to $4.02 \%$, respectively. In addition, the $\mathrm{NiO} / \mathrm{Fe}_{2} \mathrm{O}_{3}$ mixture had a poor performance in forming olefins, alkanes, and alcohols.

Supplementary Materials: The following are available online at http://www.mdpi.com/1996-1073/12/20/3972/s1, Figure S1: FTIR spectra of the Vernicia fordii wood (VF) extracts from Soxhlet extraction with either methanol, ethanol/benzene (1:1), or ethanol/ether (1:1), Figure S2: Total ion chromatogram of Vernicia fordii wood (VF) extract from methanol extraction, Figure S3: Total ion chromatogram of Vernicia fordii wood (VF) extract from ethanol/benzene extraction, Figure S4: Total ion chromatogram of Vernicia fordii wood (VF) extract from ethanol/ether extraction, Figure S5: Chemical composition of Vernicia fordii wood (VF) extracts sorted by common functional groups, Table S1: The classification of functional groups and compounds obtained from the extracts of Vernicia fordii wood (VF) from different solvent based on FTIR method, Table S2: Chemical composition of Vernicia fordii wood (VF) extract from methanol extraction, Table S3: Chemical composition of Vernicia fordii wood (VF) extract from ethanol/benzene extraction, Table S4: Chemical composition of Vernicia fordii wood (VF) extract from ethanol/ether extraction, Table S5: Chemical composition of bio-oil vapor released from fast pyrolysis of VF, Table S6: Chemical composition of bio-oil vapor released from fast pyrolysis of VF-NiO, Table S7: Chemical composition of bio-oil vapor released from fast pyrolysis of VF-Fe2O3, Table S8: Chemical composition of bio-oil vapor released from fast pyrolysis of $\mathrm{VF}-\mathrm{NiO} / \mathrm{Fe}_{2} \mathrm{O}_{3}$.

Author Contributions: Writing—original draft preparation, C.L.; investigation, X.Y., J.Y., and Y.Y.; data curation, X.Y.; writing — review and editing, C.L. and H.G.; supervision, W.P.; funding acquisition, W.P. and H.G.

Funding: This research was funded by the National Natural Science Foundation of China, grant number 41,701,360.

Acknowledgments: The authors acknowledge financial support by the National Natural Science Foundation of China (41701360). Yiyang Li has contribution on this research. Thanks for her excellent work.

Conflicts of Interest: The authors declare no conflict of interest. 


\section{References}

1. Morales, M.; Ataman, M.; Badr, S.; Linster, S.; Kourlimpinis, I.; Papadokonstantakis, S.; Hatzimanikatis, V.; Hungerbühler, K. Sustainability assessment of succinic acid production technologies from biomass using metabolic engineering. Energy Environ. Sci. 2016, 9, 2794-2805. [CrossRef]

2. Grams, J.; Niewiadomski, M.; Ruppert, A.M.; Kwapiński, W. Influence of Ni catalyst support on the product distribution of cellulose fast pyrolysis vapors upgrading. J. Anal. Appl. Pyrolysis 2015, 113, 557-563. [CrossRef]

3. Laurent, A.; Espinosa, N. Environmental impacts of electricity generation at global, regional and national scales in 1980-2011: What can we learn for future energy planning? Energy Environ. Sci. 2015, 8, 689-701. [CrossRef]

4. Morales, M.; Dapsens, P.Y.; Giovinazzo, I.; Witte, J.; Mondelli, C.; Papadokonstantakis, S.; Hungerbühler, K.; Pérez-Ramírez, J. Environmental and economic assessment of lactic acid production from glycerol using cascade bio- and chemocatalysis. Energy Environ. Sci. 2015, 8, 558-567. [CrossRef]

5. Nel, W.P.; Cooper, C.J. Implications of fossil fuel constraints on economic growth and global warming. Energy Policy 2009, 37, 166-180. [CrossRef]

6. Op de Beeck, B.; Dusselier, M.; Geboers, J.; Holsbeek, J.; Morré, E.; Oswald, S.; Giebeler, L.; Sels, B.F. Direct catalytic conversion of cellulose to liquid straight-chain alkanes. Energy Environ. Sci. 2015, 8, $230-240$. [CrossRef]

7. Vardon, D.R.; Franden, M.A.; Johnson, C.W.; Karp, E.M.; Guarnieri, M.T.; Linger, J.G.; Salm, M.J.; Strathmann, T.J.; Beckham, G.T. Adipic acid production from lignin. Energy Environ. Sci. 2015, 8, 617-628. [CrossRef]

8. Cai, H.; Wang, J.; Feng, Y.; Wang, M.; Qin, Z.; Dunn, J.B. Consideration of land use change-induced surface albedo effects in life-cycle analysis of biofuels. Energy Environ. Sci. 2016, 9, 2855-2867. [CrossRef]

9. Ding, J.; Wang, H.; Li, Z.; Cui, K.; Karpuzov, D.; Tan, X.; Kohandehghan, A.; Mitlin, D. Peanut shell hybrid sodium ion capacitor with extreme energy-power rivals lithium ion capacitors. Energy Environ. Sci. 2014, 8, 941-955. [CrossRef]

10. Mason, P.M.; Glover, K.; Smith, J.A.C.; Willis, K.J.; Woods, J.; Thompson, I.P. The potential of CAM crops as a globally significant bioenergy resource: Moving from 'fuel or food' to 'fuel and more food'. Energy Environ. Sci. 2015, 8, 2320-2329. [CrossRef]

11. Jung, J.I.; Risch, M.; Park, S.; Kim, M.G.; Nam, G.; Jeong, H.Y.; Shao-Horn, Y.; Cho, J. Optimizing nanoparticle perovskite for bifunctional oxygen electrocatalysis. Energy Environ. Sci. 2016, 9, 176-183. [CrossRef]

12. Liu, B.; Zhang, Z. Catalytic Conversion of Biomass into Chemicals and Fuels over Magnetic Catalysts. ACS. Catal. 2015, 6, 326-338. [CrossRef]

13. Shi, M.; Zhang, P.; Fan, M.; Jiang, P.; Dong, Y. Influence of crystal of $\mathrm{Fe}_{2} \mathrm{O}_{3}$ in magnetism and activity of nanoparticle $\mathrm{CaO} / \mathrm{Fe}_{2} \mathrm{O}_{3}$ for biodiesel production. Fuel 2017, 197, 343-347. [CrossRef]

14. Bridgwater, A.V. Production of high grade fuels and chemicals from catalytic pyrolysis of biomass. Catal. Today 1996, 29, 285-295. [CrossRef]

15. Kunkes, E.L.; Simonetti, D.A.; West, R.M.; Serrano-Ruiz, J.C.; Gärtner, C.A.; Dumesic, J.A. Catalytic conversion of biomass to monofunctional hydrocarbons and targeted liquid-fuel classes. Science 2008, 322, 417-421. [CrossRef]

16. Hara, M. Biomass conversion by a solid acid catalyst. Energy Environ. Sci. 2010, 3, 601-607. [CrossRef]

17. Duan, X.F.; Zhou, Z.F.; Xu, J.M.; Tian, Y.; Wang, R. Utilization situation and suggestion of forestry residues resources in China. China Wood Panel 2017, 24, 1-5.

18. Lu, Q.; Zhang, Z.F.; Dong, C.Q.; Zhu, X.F. Catalytic Upgrading of Biomass Fast Pyrolysis Vapors with Nano Metal Oxides: An Analytical Py-GC/MS Study. Energies 2010, 3, 1805-1820. [CrossRef]

19. Banks, S.W.; Nowakowski, D.J.; Bridgwater, A.V. Impact of Potassium and Phosphorus in Biomass on the Properties of Fast Pyrolysis Bio-oil. Energy Fuels 2016, 30, 8009-8018. [CrossRef]

20. Chen, X.; Yang, H.; Chen, Y.; Chen, W.; Lei, T.; Zhang, W.; Chen, H. Catalytic fast pyrolysis of biomass to produce furfural using heterogeneous catalysts. J. Anal. Appl. Pyrolysis 2017, 127, 292-298. [CrossRef]

21. Jae, J.; Coolman, R.; Mountziaris, T.J.; Huber, G.W. Catalytic fast pyrolysis of lignocellulosic biomass in a process development unit with continual catalyst addition and removal. Chem. Eng. Sci. 2014, 108, 33-46. [CrossRef] 
22. Liu, Q.; Zhong, Z.; Wang, S.; Luo, Z. Interactions of biomass components during pyrolysis: A TG-FTIR study. J. Anal. Appl. Pyrolysis 2011, 20, 213-218. [CrossRef]

23. Wang, K.; Kim, K.H.; Brown, R.C. Catalytic pyrolysis of individual components of lignocellulosic biomass. Green Chem. 2014, 16, 727-735. [CrossRef]

24. Yu, J.; Paterson, N.; Blamey, J.; Millan, M. Cellulose, xylan and lignin interactions during pyrolysis of lignocellulosic biomass. Fuel 2017, 191, 140-149. [CrossRef]

25. Li, J.; Yan, R.; Xiao, B.; Liang, D.T.; Du, L. Development of nano-NiO/Al2O3 catalyst to be used for tar removal in biomass gasification. Environ. Sci. Technol. 2008, 42, 6224-6229. [CrossRef] [PubMed]

26. Zou, J.; Oladipo, J.; Fu, S.L.; Al-Rahbib, A.; Yang, H.P.; Wu, C.F.; Cai, N.; Williams, P.; Chen, H.P. Hydrogen production from cellulose catalytic gasification on $\mathrm{CeO}_{2} / \mathrm{Fe}_{2} \mathrm{O}_{3}$ catalyst. Energy Conves. Mang. 2018, 171, 241-248. [CrossRef]

27. Xie, Y.; Ge, S.; Jiang, S.; Liu, Z.; Chen, L.; Wang, L.; Chen, J.; Qin, L.; Peng, W. Study on biomolecules in extractives of Camellia oleifera fruit shell by GC-MS. Saudi J. Biol. Sci. 2018, 25, 234-236. [CrossRef]

28. Khelfa, A.; Sharypov, V.; Finqueneisel, G.; Weber, J.V. Catalytic pyrolysis and gasification of Miscanthus Giganteus: Haematite $\left(\mathrm{Fe}_{2} \mathrm{O}_{3}\right)$ a versatile catalyst. J. Anal. Appl. Pyrolysis 2009, 84, 84-88. [CrossRef]

29. Peng, W.; Lin, Z.; Wang, L.; Chang, J.; Gu, F.; Zhu, X. Molecular characteristics of Illicium verum extractives to activate acquired immune response. Saudi J. Biol. Sci. 2016, 23, 348-352. [CrossRef]

30. Li, C.; Zhang, J.; Yi, Z.; Yang, H.; Zhao, B.; Zhang, W.; Li, J. Preparation and characterization of a novel environmentally friendly phenol-Formaldehyde adhesive modified with tannin and urea. Int. J. Adhes. Adhes. 2016, 66, 26-32. [CrossRef]

31. Lu, Q.; Zhang, Z.B.; Yang, X.C.; Dong, C.Q.; Zhu, X.F. Catalytic fast pyrolysis of biomass impregnated with K3PO4 to produce phenolic compounds: Analytical Py-GC/MS. J. Anal. Appl. Pyrolysis 2013, 104, 139-145. [CrossRef]

32. Sun, L.; Zhang, X.; Chen, L.; Zhao, B.; Yang, S.; Xie, X. Comparision of catalytic fast pyrolysis of biomass to aromatic hydrocarbons over ZSM-5 and Fe/ZSM-5 catalysts. J. Anal. Appl. Pyrolysis 2016, 121, 342-346. [CrossRef]

33. Peyrat-Maillard, M.N.; Cuvelier, M.E.; Berset, C. Antioxidant activity of phenolic compounds in 2, 2-azobis (2-amidinopropane) dihydrochloride (AAPH)-induced oxidation Synergistic and antagonistic effects. JOACS 2003, 80, 1007-1012. [CrossRef]

34. Ikeda, I.; Tanabe, Y.; Sugano, M. Effects of Sitosterol and Sitostanol on Micellar solubility of Cholesterol. J. Nutr. Sci. Vitaminol. 1989, 35, 361-369. [CrossRef] [PubMed]

35. Salen, G.; Shore, V.; Tint, G.S.; Forte, T.; Shefer, S.; Horak, I.; Horak, E.; Dayal, B.; Nguyen, L.; Batta, A.K. Increased sitosterol absorption, decreased removal, and expanded body pools compensate for reduced cholesterol synthesis in sitosterolemia with xanthomatosis. J. Lip. Res. 1989, 30, 1319-1330.

36. Luterbacher, J.S.; Azarpira, A.; Motagamwala, A.H.; Lu, F.; Ralph, J.; Dumesic, J.A. Lignin monomer production integrated into the $\gamma$-valerolactone sugar platform. Energy Environ. Sci. 2015, 8, 2657-2663. [CrossRef]

37. Rinaldi, R.; Schüth, F. Design of solid catalysts for the conversion of biomass. Energy Environ. Sci. 2009, 2, 610. [CrossRef]

38. Li, D.L.; Wu, J.Q.; Peng, W.X.; Xiao, W.F.; Wu, J.G.; Zhuo, J.Y.; Yuan, T.Q.; Sun, R.C. Effect of lignin on bamboo biomass self-bonding during hot-pressing lignin structure and characterization. Bioresources 2015, 10, 6769-6782. [CrossRef]

39. Burhenne, L.; Messmer, J.; Aicher, T.; Laborie, M.P. The effect of the biomass components lignin, cellulose and hemicellulose on TGA and fixed bed pyrolysis. J. Anal. Appl. Pyrolysis 2013, 101, 177-184. [CrossRef]

40. Chen, Z.; Hu, M.; Zhu, X.; Guo, D.; Liu, S.; Hu, Z.; Xiao, B.; Wang, J.; Laghari, M. Characteristics and kinetic study on pyrolysis of five lignocellulosic biomass via thermogravimetric analysis. Bioresour. Technol. 2015, 192, 441-450. [CrossRef]

41. Ondro, T.; Vitázek, I.; Húlan, T.K.; Lawson, M.; Csáki, Š. Non-isothermal kinetic analysis of the thermal decomposition of spruce wood in air atmosphere. Res. Agric. Eng. 2018, 64, 41-46.

42. Biagini, E.; Barontini, F.; Tognotti, L. Devolatilization of biomss fuels and biomass components stutied by TG/FTIR technique. Ind. Eng. Chem. Res. 2006, 45, 4486-4493. [CrossRef]

43. Balat, M. Mechanisms of thermochemical biomass conversion processes. Part 1: Reactions of pyrolysis. Energy Sour. Part A 2008, 30, 620-635. [CrossRef] 
44. Demirbas, A. Biofuels securing the plant's future energy needs. Energ. Convers. Manag. 2009, 50, $2239-2249$. [CrossRef]

45. Zhao, C.; Jiang, E.; Chen, A. Volatile production from pyrolysis of cellulose, hemicellulose and lignin. J. Energy Inst. 2017, 90, 902-913. [CrossRef]

46. Xing, S.; Yuan, H.; Huhetaoli Qi, Y.; Lv, P.; Yuan, Z.; Chen, Y. Characterization of the decomposition behaviors of catalytic pyrolysis of wood using copper and potassium over thermogravimetric and Py-GC/MS analysis. Energy 2016, 114, 634-646. [CrossRef]

47. Svenson, J.; Pettersson, J.B.C.; Davidsson, K.O. Fast Pyrolysis of the Main Components of Birch Wood. Combust. Sci. Technol. 2004, 176, 977-990. [CrossRef]

48. Zhang, X.; Yang, W.; Blasiak, W. Thermal decomposition mechanism of levoglucosan during cellulose pyrolysis. J. Anal. Appl. Pyrolysis 2012, 96, 110-119. [CrossRef]

49. Zhang, X.; Yang, W.; Dong, C. Levoglucosan formation mechanisms during cellulose pyrolysis. J. Anal. Appl. Pyrolysis 2013, 104, 19-27. [CrossRef]

50. Vitázek, I.; Tkáč, Z. Isothermal kinetic analysis of thermal decomposition of woody biomass: The thermogravimetric study. AIP Conf. Proc. 2019, 2118. [CrossRef]

51. Wang, H.; Lee, S.J.; Olarte, M.V.; Zacher, A.H. Bio-oil Stabilization by Hydrogenation over Reduced Metal Catalysts at Low Temperatures. ACS Sustain. Chem. Eng. 2016, 4, 5533-5545. [CrossRef]

52. Papari, S.; Hawboldt, K.; Helleur, R. Production and Characterization of Pyrolysis Oil from Sawmill Residues in an Auger Reactor. Ind. Eng. Chem. Res. 2017, 56, 1920-1925. [CrossRef]

53. Fushimi, C.; Katayama, S.; Tsutsumi, A. Elucidation of interaction among cellulose, lignin and xylan during tar and gas evolution in steam gasification. J. Anal. Appl. Pyrolysis 2009, 86, 82-89. [CrossRef]

54. Gani, A.; Naruse, I. Effect of cellulose and lignin content on pyrolysis and combustion characteristics for several types of biomass. Renew. Energy 2007, 32, 649-661. [CrossRef]

55. Giudicianni, P.; Cardone, G.; Ragucci, R. Cellulose, hemicellulose and lignin slow steam pyrolysis: Thermal decomposition of biomass components mixtures. J. Anal. Appl. Pyrolysis 2015, 100, 213-222. [CrossRef]

56. Hosoya, T.; Kawamoto, H.; Saka, S. Cellulose-Hemicellulose and cellulose-Lignin interactions in wood pyrolysis at gasification temperature. J. Anal. Appl. Pyrolysis 2007, 80, 118-125. [CrossRef]

57. Caballero, J.A.; Font, R.; Marcilla, A. Comparative study of the pyrolysis of almond shells and their fractions, holocellulose and lignin: Product yields and kinetics. Thermochim. Acta 1996, 276, 57-77. [CrossRef]

58. Lu, Q.; Dong, C.Q.; Zhang, X.M.; Tian, H.Y.; Yang, Y.P.; Zhu, X.F. Selective fast pyrolysis of biomass impregnated with $\mathrm{ZnCl}_{2}$ to produce furfural: Analytical Py-GC/MS study. J. Anal. Appl. Pyrolysis 2011, 90, 204-212. [CrossRef]

59. Mettler, M.S.; Mushrif, S.H.; Paulsen, A.D.; Javadekar, A.D.; Vlachos, D.G.; Dauenhauer, P.J. Revealing pyrolysis chemistry for biofuels production: Conversion of cellulose to furans and small oxygenates. Energy Environ. Sci. 2012, 5, 5414-5424. [CrossRef]

60. Zhang, B.; Zhong, Z.; Ding, K.; Cao, Y.; Liu, Z. Catalytic Upgrading of Corn Stalk Fast Pyrolysis Vapors with Fresh and Hydrothermally Treated HZSM-5 Catalysts Using Py-GC/MS. Ind. Eng. Chem. Res. 2014, 53, 9979-9984. [CrossRef]

61. Imrana, A.; Bramer, E.A.; Seshanb, K.; Brem, G. Catalytic flash pyrolysis of oil-impregnated-wood and jatropha cake using sodium based catalysts. J. Anal. Appl. Pyrolysis 2016, 117, 236-246. [CrossRef]

(C) 2019 by the authors. Licensee MDPI, Basel, Switzerland. This article is an open access article distributed under the terms and conditions of the Creative Commons Attribution (CC BY) license (http://creativecommons.org/licenses/by/4.0/). 